\title{
Deviation Category Code
}

National Cancer Institute

\section{Source}

National Cancer Institute. Deviation Category Code. NCI Thesaurus. Code C93551.

A coded value specifying a classification of a deviation. 